\title{
Revisiting tourist behavior via destination brand worldness
}

\author{
Murat Kayak $^{\mathrm{a}^{*}}$ and Michele Simoni ${ }^{\mathrm{b}}$
}

${ }^{a} P h D$ student in Management, XXX Cycle, Department of Business and Quantitative Studies, University of Naples "Parthenope”, Italy

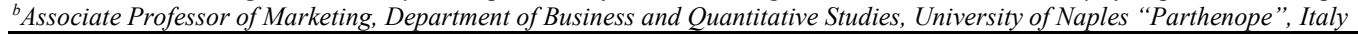

\section{H R O N I C L E}

Article history:

Received September 5, 2016

Received in revised format

October 2, 2016

Accepted October 12, 2016

Available online

October 12, 2016

Keywords:

Taiwan

Tourism destination brand

worldness

Intention to revisit

\section{A B S T R A C T}

\begin{abstract}
Taking tourists' perspective rather than destination offerings as its core concept, this study introduces "perceived destination brand worldness" as a variable. Perceived destination brand worldness is defined as the positive perception that a tourist has of a country that is visited by tourists from all over the world. Then, the relationship between perceived destination brand worldness and intention to revisit is analyzed using partial least squares regression. This empirical study selects Taiwanese tourists as its sample, and the results show that perceived destination brand worldness is a direct predictor of intention to revisit. In light of these empirical findings and observations, practical and theoretical implications are discussed.
\end{abstract}

(C) 2016 Growing Science Ltd. All rights reserved.

\section{Introduction}

A number of empirical studies have explored the importance of branding in destination management. For example, Park and Petrick (2006) measured destinations' perspectives of branding. Qu et al. (2011) developed and tested a theoretical model of destination branding that integrates the concepts of destination branding and destination image. The findings of prior researches confirm that destination branding is a cornerstone of destination management (Hanlan \& Kelly, 2005; Tasci et al., 2007; Tasci \& Kozak, 2006; Park \& Petrick, 2006; Qu et al., 2011). In light of past findings, academics have proceeded one step further by developing a destination brand equity model. For example, testing in Slovenian markets, Konecnic and Gartner (2007) introduced a customer-based brand equity model. The measurement model of brand equity employs the dimensions of awareness, quality, loyalty and image. Boo et al. (2009) employed a customer-based brand equity model that employed an online survey sample of Las Vegas and Atlantic City visitors (the first model consisted of awareness, image, quality, value and loyalty, whereas the second model consisted of awareness, value, experience [image and quality] and loyalty). Despite extensive research on destination branding (Boo et al., 2009; Kim \& Kim, 
2005; Kladou \& Kehagias, 2014; Konecnik \& Gartner, 2007; Lee \& Back, 2008), there has been no research that has clarified tourists' intention to revisit by analyzing the "world image of a destination". It is widely acknowledged that destination image is a predecessor step to destination branding (e.g., Qu et al., 2011). Taking tourists' perspective rather than destination offerings as its core concept, this study aims to introduce "perceived destination brand worldness" as a variable for evaluating the tourist stay. Perceived destination brand worldness is defined as the positive perception that a tourist has of a destination that is visited by people from several different countries of the world. This study argues that academics should consider the worldness image of a destination in evaluating intention to revisit.

The purpose of this study is to clarify the relationship between perceived destination brand worldness and intention to revisit. This empirical study employs Taiwanese tourists as its sample for no particular reason except that a co-author is familiar with Taiwan, and the empirical results show that "perceived destination brand worldness" is a direct predictor of intention to revisit. In light of the empirical findings and observations, practical and theoretical implications are discussed.

\section{Theoretical background}

\subsection{Definition of destination image and destination branding}

Crompton (1972) defined image as “... the sum of beliefs, ideas, and impressions that a person has of a destination" (p. 18). Moreover, as Baloglu and Brinberg (1997) asserted, "Image differentiates tourist destinations from one another and is an integral and influential part of travelers' decision process" (p. 11). Cai (2002) described the image of a destination brand as "... perceptions about the place as reflected by the associations held in tourist memory" (p. 723) and further defined destination branding as "...,selecting a consistent element mix to identify and distinguish it through positive image building. A brand element comes in the form of a name, term, logo, sign, design, symbol, slogan, package, or a combination of these, of which the name is the first and foremost reference. However, unlike typical goods and services, the name of a destination brand is relatively fixed by the actual geographical name of the place. Because of its given nature and people's unconscious awareness that it cannot be changed, the name is typically absent in destination image studies" (p. 722). In addition, and also according to Cai (2002), "The challenge of branding destinations lies with the complexity of the decision process on the part of tourists" (p. 721).

Considering that image is an important element in travelers' decision-making processes (e.g., Baloglu \& Brinberg, 1997), managing destination image is important and involves formulating a strong positioning strategy. Because building a unique brand image is important for gaining competitive advantage, identifying the particular dimensions of a specific destination is not only important for managing destinations strategically but also important for building strong brand equity for long-term growth (Qu et al., 2011).

\subsection{Research hypothesis}

Although destination image and destination branding have been widely investigated in the tourism management literature (e.g., Konecnik \& Gartner, 2007; Qu et al., 2011), there has been no research that has focused in particular on the world image of a destination or on a tourist's perception of a destination that attracts tourists from all over the world. This study claims that world image is nonetheless a prominent strategy for destination branding.

Therefore, this study argues that it is time for the tourism management literature to distinguish among the different types of destination images (e.g., world image, global image, local image, etc.). Destinations are like products, but a destination cannot physically enter into multiple countries (e.g., Steenkamp et al., 2003; Strizhakova et al., 2011). Therefore, to measure a destination's world image, 
this construct can be conceptualized only by highlighting that tourists from multiple countries have visited the destination. In other words, a destination could enter a new market by building a global image worldwide (i.e., a destination that attracts tourists from all over the world). Therefore, this study introduces destination brand worldness. Destination brand worldness is defined as a world tourism destination that attracts travelers from multiple countries. Then, taking tourists' view, perceived destination brand worldness is defined as the positive perception that a tourist has of country that attracts international visitors. Keller (1993) defines brand image as "the set of associations linked to the brand that consumers hold in memory" (p. 2). Thus, analyzing the relationship between perceived destination brand worldness and intention to revisit is meaningful, as it helps destination managers differentiate their destinations by being aware of destination brand worldness. Specifically, a global brand enters multiple countries, and this perception explains the purchasing behavior of some consumers in the global marketplace (Strizhakova, et al., 2011). Similarly, if a destination is perceived as a world image, this might be important for some travelers' destination choice. This study therefore argues that travelers might think that a destination hosts tourists from multiple countries, which might have a positive impact on travelers' intention to revisit. Thus, hypothesis 1 is formulated as follows:

H1 Tourism destination brand worldness positively affects intention to revisit.

\section{Methodology}

Aiming to explore the relationship between destination brand worldness and intention to revisit, the research hypothesis is tested using the following methods.

\subsection{Sample selection and data collection}

This empirical study selects Taiwanese tourists as the relevant sample in which to test the hypothesis. A questionnaire designed by the authors was originally developed in English and consisted of two parts, in addition to an introduction describing the research objective. The questionnaire was based on "Tourists' Favorite Tourism Destination" that tourists had previously visited, for two reasons. First, this study argues that the concept of tourists' favorite destination is an important contribution to the literature, as it allows exploration of whether destination brand worldness affects the travel intention of Taiwanese tourists regarding any visited destination. Second, asking a tourist about his/her favorite tourism destination enables the study to consider respondents' thoughts about their own favorite destination and avoid the bias associated with destination awareness. Therefore, after introducing the research objective, the question of tourists' favorite tourism destination was placed in the questionnaire.

To collect data in Taiwan, the English version of the questionnaire was sent by e-mail to be translated into traditional Chinese. After translation, an online survey questionnaire was designed on Google, www.google.com, and the link was sent by e-mail via self-administrated survey. One hundred five participants completed the survey questionnaire. After data were collected, the questionnaire's traditional Chinese was translated back into English. The questionnaire translation was performed by a Taiwanese citizen with both academic and industrial experience in research and development. All the participants answered the question "Your Favorite Tourism Destination."

\subsection{Measures}

At the stage of scale development, all items were discussed in person with scholars who have research experience in management. As recommended, construct validity was pre-tested (Cooper \& Schindler, 2011; Hair et al., 2010). Thereafter, a preliminary pre-test was administered to a group of academic experts. The destination brand worldness scale was newly developed based on the studies by Kayak et al. (2013), Steenkamp et al. (2003) and Strizhakova et al. (2011). This study adopts four-item scales 
for intention to revisit from Horng et al. (2012) and Kim et al. (2009). Respondents were to rate using a 7-point Likert scale, with "strongly disagree - 1" and "strongly agree - 7."

\subsection{Data analysis}

Data screening procedures were examined for missing cases, outliers and scale by using the following statistical methods. Normality was evaluated through calculation of the mean, standard deviations, skewness and kurtosis for each item in SPSS (Tabachnick \& Fidell, 2001). Next, an exploratory factor analysis with promax rotation was conducted because the constructs are correlated (Hair et al., 2010). Then, the internal consistency of each factor identified in the exploratory factor analysis was examined by calculating Cronbach's alphas for reliability. Next, common method variance was examined because a single survey method was used to measure independent and dependent variables (Lindell \& Whitney, 2001). Finally, the theoretical model was implemented using SmartPLS 3.0. SmartPLS is a structural equation modeling (SEM) package based on the partial least squares (PLS) method of assessing a measurement model and a structural model. PLS-SEM is a powerful method for identifying key driver constructs in small samples (Hair, Ringle, \& Sarstedt, 2011), which fits the aim of this research, which uses a small sample to analyze a new specific latent variable, perceived destination worldness, as a predictor for intention to revisit.

\section{Results}

\subsection{Data screening and assessing normality}

There were no missing values. Possible outliers were detected by calculating the $\mathrm{z}$ value (Tabachnick \& Fidell, 2001). A smaller sample size with an absolute value of 2.58 was appropriate; therefore, detected outliers were removed from the sample (Tabachnick \& Fidell, 2001). Means and standard deviations for the individual items are shown in Table 1 . The response variability was satisfactory because standard deviations for the individual items are greater than or close to $+1.00,-1.00$. The majority of items were distributed within the adequate levels. The means, standard deviations, skewness and kurtosis for each item are presented in Table 1.

Table 1

Normality, skewness, kurtosis, means and standard deviations

\begin{tabular}{ccccc}
\hline Item & Mean & Std. Deviations & Skewness & Kurtosis \\
\hline TDBW1 & 5.66 & 1.206 & -0.851 & 0.147 \\
TDBW2 & 5.82 & 1.163 & -0.936 & 0.605 \\
TDBW3 & 5.26 & 1.258 & -0.681 & 0.81 \\
TDBW4 & 5.54 & 1.248 & -0.747 & 0.31 \\
TDBW5 & 5.38 & 1.336 & -0.703 & 0.18 \\
TI1 & 6.08 & 1.08 & -0.877 & -0.3 \\
TI2 & 6.12 & 0.979 & -1.03 & 0.525 \\
TI3 & 5.83 & 1.193 & -0.869 & 0.157 \\
\hline
\end{tabular}

\subsection{Profile of the respondents}

After the data screening procedures, 76 data items remained (Tabachnick \& Fidell, 2001). Table 2 shows the profile of respondents. There were more female $(63.2 \%)$ than male $(36.8 \%)$ participants. In addition, respondents articulated a total of 14 destinations, and the most cited tourism destination was Japan $(64.5 \%)$. 
Table 2

Profile of demographic characteristics

\begin{tabular}{crr}
\hline Variables & Frequency & Percent \\
\hline Gender & & \\
\hline Male & 28 & 36.8 \\
\hline Female & 48 & 63.2 \\
\hline Total & 76 & 100.0 \\
\hline Age & & 10.5 \\
\hline $20-29$ & 8 & 69.7 \\
\hline $30-39$ & 53 & 17.1 \\
\hline $40-49$ & 13 & 1.3 \\
\hline $50-59$ & 1 & 1.3 \\
\hline $60-69$ & 1 & 100.0 \\
\hline Total & 76 & 28.9 \\
\hline Income (NT\$) & & 38.2 \\
\hline Under 40,000 & 22 & 19.7 \\
\hline $40,000-700,000$ & 29 & 13.2 \\
\hline 700,001-1,100,000 & 15 & 100.0 \\
\hline Over $1,100,000$ & 10 & \\
\hline Total & 76 & 14.5 \\
\hline Education & & 65.8 \\
\hline Senior High School & 11 & 15.8 \\
\hline Bachelor & 50 & 2.6 \\
Master & 12 & 1.3 \\
\hline PhD & 2 & 100.0 \\
\hline Special College & 1 &
\end{tabular}

\subsection{Exploratory Factor Analysis}

An exploratory factor analysis was conducted with promax rotation. The Kaiser-Meyer-Olkin statistic of 0.822 indicates that the data are appropriate for factor analysis. Two factors emerged. The results showed that items were cleanly and separately loaded onto the corresponding factors. However, two items were removed based on low loadings. Therefore, the two items were discarded from the analysis, reducing the scale to 8 items. Then, 8 items were entered for the next run, and two factors based on eigenvalues over 1.0 were extracted. All items loaded cleanly and highly onto the two factors, representing destination brand worldness and intention to revisit, as shown in Table 3.

Table 3

Exploratory factor analysis (EFA)

\begin{tabular}{ccc}
\hline Item & Destination brand worldness & Intention to revisit \\
\hline TDBW1 & $\mathbf{. 8 0 8}$ & .528 \\
TDBW2 & $\mathbf{. 8 6 6}$ & .598 \\
TDBW3 & $\mathbf{. 9 0 3}$ & .393 \\
TDBW4 & $\mathbf{. 8 7 4}$ & .371 \\
TDBW5 & $\mathbf{8 2 0}$ & .279 \\
TI1 & .490 & $\mathbf{9 4 4}$ \\
TI2 & .426 & $\mathbf{. 9 6 2}$ \\
TI3 & .403 & $\mathbf{. 9 1 7}$ \\
\hline Eigenvalue & 4.791 & 1.616 \\
\hline
\end{tabular}

Total variance extracted by the two factors was $80.079 \%$

Cronbach's alphas: worldness scale: 0.907 , intention to revisit scale: 0.934 , overall scale: 0.901 


\subsection{Validity and reliability of the measurement model}

The measurement model was tested for reliability and validity using SmartPLS 3.0. Composite reliability and average variance explained (AVE) of perceived destination brand worldness and intention to revisit are shown in Table 4. The composite reliability for each of the latent variables was greater than 0.80 , and the AVE was higher than 0.50, indicating strong reliability and convergent validity, respectively.

\section{Table 4}

Composite reliability and AVE

\begin{tabular}{ccc}
\hline Latent variable & Composite reliability & AVE \\
\hline Intention to revisit & 0.961 & 0.892 \\
Destination brand worldness & 0.931 & 0.729 \\
\hline
\end{tabular}

Table 5 presents the ratio of the square root of the AVE of each reflective latent variable and the correlation coefficients between perceived destination brand worldness and intention to revisit. The diagonal elements in parentheses are the correlations of each construct with its own measure, which is the square root of the AVE. Off-diagonal elements include correlations between constructs. Diagonal elements should be larger than the entries in the corresponding rows and columns for adequate discriminant validity. Clearly, each construct is more highly correlated with its own measure than with any other constructs, indicating strong discriminant validity under the Fornell-Larcker criterion. In addition, a new criterion for assessing discriminant validity (Henseler, Ringle, \&, Sarstedt, 2015) shows that the highest value of heterotrait-monotrait ratio of correlations (HTMT) is 0.530, which is below 0.85 and thus supports discriminant validity. Furthermore, HTMT inference criteria also shows that the upper confidence interval limit is 0.730 (destination brand worldness to intention to revisit), which is less than 1 and thus offers additional support for discriminant validity (Henseler et al., 2015).

\section{Table 5}

Correlations of the latent variables and the square root of AVE

\begin{tabular}{lcc}
\hline Latent variable & Intention to revisit & Destination brand worldness \\
\hline Intention to revisit & $(0944)$ & \\
Destination brand worldness & 0.511 & $(0.854)$ \\
\hline
\end{tabular}

In addition, the loadings and cross-loadings of the items compared across all latent variables show strong convergent validity with high loading scores (all higher than 0.7 ), as Table 6 shows.

\section{Table 6}

\begin{tabular}{ccc} 
Cross-loadings matrix & & \\
\hline Item & Intention to revisit & Destination brand worldness \\
\hline TDBW1 & 0.483 & $\mathbf{0 . 8 5 5}$ \\
TDBW2 & 0.556 & $\mathbf{0 . 9 0 9}$ \\
TDBW3 & 0.381 & $\mathbf{0 . 8 9 2}$ \\
TDBW4 & 0.384 & $\mathbf{0 . 8 3 7}$ \\
\hline TDBW5 & 0.297 & $\mathbf{0 . 7 7 1}$ \\
TI1 & $\mathbf{0 . 9 5 3}$ & 0.525 \\
TI2 & $\mathbf{0 . 9 6 3}$ & 0.471 \\
TI3 & $\mathbf{0 . 9 1 6}$ & 0.444 \\
\hline
\end{tabular}

\subsection{Common method variance and theoretical model validation}

In addition, this study attempted to control the potential impact of common method variance, as a single survey was used to measure the latent variables. The items were specifically developed by reviewing 
the relevant literature, and the study introduces and adopts the destination brand worldness construct based on the previous literature. Furthermore, "season" is included as a marker variable to check common method bias, which is theoretically an unrelated variable (Lindell \& Whitney, 2001). Thus, the relationship among destination brand worldness, intention to revisit and season as a marker variable was evaluated, and the findings showed that season has no significant correlation with the study variables, offering additional evidence for discriminant validity. In other words, these findings show that common method variance does not significantly affect the relationship among the latent variables (i.e., destination brand worldness and intention to revisit) in this study, as shown in Table 7.

Table 7

Correlations among destination brand worldness, intention to travel and season

\begin{tabular}{ccccc}
\hline & & $\begin{array}{c}\text { Destination brand } \\
\text { worldness }\end{array}$ & $\begin{array}{c}\text { Intention to } \\
\text { revisit }\end{array}$ & Season \\
\hline $\begin{array}{c}\text { Destination } \\
\text { brand } \\
\text { worldness }\end{array}$ & Pearson Correlation & 1 & $.484^{* * *}$ & .048 \\
\hline $\begin{array}{c}\text { Intention to } \\
\text { travel }\end{array}$ & Pig. (2-tailed) & $\mathrm{N}$ & .000 & .683 \\
& Pearson Correlation & $.484^{* *}$ & 76 & 76 \\
\hline Season & Sig. (2-tailed) & .000 & 1 & .112 \\
& Pearson Correlation & .048 & 76 & .336 \\
& Sig. (2-tailed) & .683 & .112 & 76 \\
\hline **. Correlation is significant at the 0.01 level (2-tailed) & 76 & .336 & 76 \\
\hline
\end{tabular}

\subsection{Hypothesis testing}

Fig. 1 shows the results of the hypothesis testing. The path coefficient of perceived destination brand worldness to intention to revisit $(\beta=511)$ is significant at $p<0.001$, supporting H1. Perceived destination brand worldness explains $26 \%$ of the variance in intention to revisit.

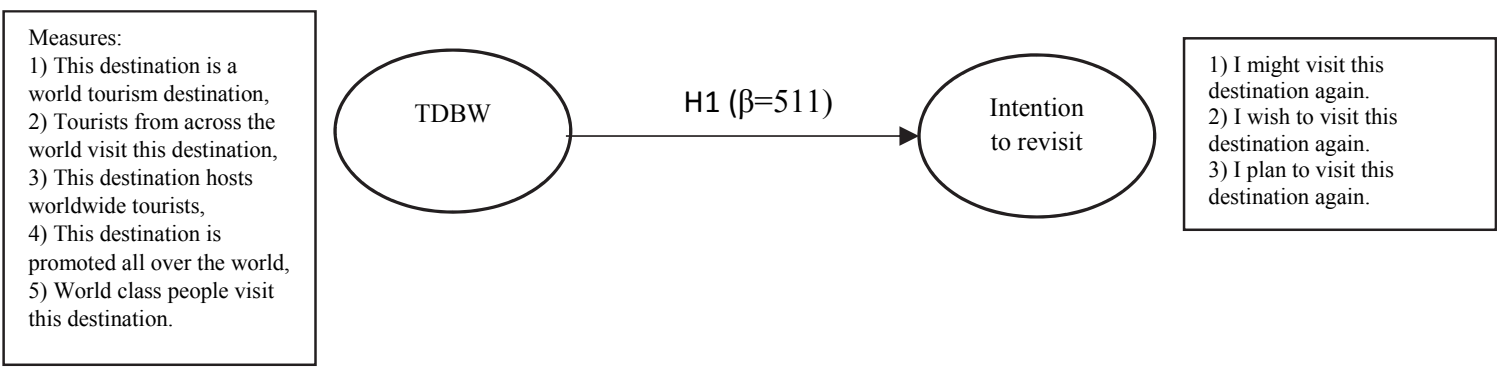

Fig. 1. Theoretical model

\subsection{Discussion}

The purpose of this study was to explore whether perception of destination brand worldness explains intention to revisit. The empirical evidence shows that destination brand worldness positively and significantly affects Taiwanese tourists' intention to revisit.

\subsection{Theoretical implications}

In terms of the complexity of measuring destination branding and travel intention, this study provides evidence to fill a gap in the relevant literature, along with other comparable research (Konecnik \& 
Gartner, 2007; Horng et al., 2012). It is not possible to fully compare this study with prior research (Konecnik \& Gartner, 2007; Horng et al., 2012) because it introduces a new construct, the "world image" of a destination. This feature makes the present study unique, as it empirically tests a previously untested relationship between destination brand worldness and intention to revisit. The findings show that destination brand worldness positively affects intention to revisit. This new construct is meaningful and an important contribution to the literature in terms of understanding how tourists evaluate a destination.

It is important to note that Horng et al. (2012) explored travelers' intentions to visit Taiwan, whereas Boo et al. (2009) selected Las Vegas and Atlantic City as destination brands. To measure destination branding, a destination must be well known; therefore, this study inquired about respondents' favorite tourism destination to test whether destination brand worldness is an important predictor in any destination that a respondent would like to visit. This was important because tourists' favorite tourism destination allows measurement of the destination that is already in the mind of its travelers (Keller, 1993). As this study is among the first to test a destination branding model by building a questionnaire based on "Tourists' Favorite Tourism Destination," both its research design and findings might be helpful to other researchers in destination management.

\subsection{Practical Implications}

Destination managers are under pressure to create competitive advantage in the global marketplace (e.g., Qu et al., 2011; Konecnik and Gurtner, 2007; Boo et al., 2009), and this study's findings hold several important implications for destination managers. As stated by Boo et al. (2009), measuring different dimensions is important to create destination brand equity in target markets and can increase competitiveness by raising destination awareness. The findings of this study highlight that destination brand worldness has a significant impact on intention to revisit. This finding is crucial in that it provides a solution for the most pressing challenge of destination managers in a competitive global marketplace. Practitioners should be aware of destination brand worldness, for it is an important predictor of Taiwanese travelers' destination choice. The recommendation for destination managers might be to concentrate their efforts on the development of destination brand worldness to make their destination image more competitive in the Taiwanese market. In other words, the empirical evidence specifically suggests that managers should concentrate on the brand worldness variable when developing a strategy to attract Taiwanese tourists.

The following five-item destination brand worldness scale was developed and tested: (1) this destination is a world tourism destination, (2) tourists from across the world visit this destination, (3) this destination hosts worldwide tourists, (4) this destination is promoted all over the world, and (5) world class people visit this destination. Japan was the most cited tourism destination, and destination brand worldness explains Taiwanese travelers' intention to travel. Thereby, as a part of their branding strategy, destination managers in Japan can formulate a world image to attract more travelers from Taiwan by means of their promotional programs. Other destinations with a world image can also develop a world image-based strategy in their promotional programs for Taiwanese travelers. A destination can adopt destination brand worldness by implementing strategies to attract tourists from multiple countries.

According to the targeted markets, the five-item destination brand worldness scale may easily be adopted by practitioners to measure travelers' perception of a destination's worldness and to determine whether it is an important driver. If worldness is significant, the same strategy can be implemented in those destinations to attract more travelers. Based on this study's research design, it is clear that there is a growing opportunity to capture value by managing and developing destination brand worldness and to put a particular destination in the minds of Taiwanese travelers (Konecnik \& Gartner, 2007). 


\subsection{Limitations}

Although gender was not expressly limited, most of the participants in this study were female (63.2\%); therefore, the findings are based on mostly female participants aged between 30 and 39. Moreover, the findings are limited to Taiwanese travelers. Further research should be conducted among other nationalities for generalizability.

\section{Conclusion}

This research aimed to introduce a new variable, destination brand worldness, and to determine whether destination brand worldness explains intention to revisit a tourist destination. Primary data were collected in Taiwan to test the research hypothesis. A destination brand worldness scale was developed and validated. The study concludes that destination brand worldness is a prominent construct that has a positive impact on intention to revisit.

\section{References}

Baloglu, S., \& Brinberg, D. (1997). Affective images of tourism destinations. Journal of Travel Research, 35(4), 11-15.

Boo, S., Busser, B., \& Baloglu, S. (2009). A model of customer-based brand equity and its application to multiple destinations. Tourism Management, 30(2), 219-231.

Cai, L. A. (2002). Cooperative branding for rural destinations. Annals of Tourism Research, 29(3), 720742.

Cooper, D. R., \& Schindler, P. S. (2011). Business Research Methods (11th Ed.). NY: McGraw-Hill.

Crompton, J. L. (1972). An assessment of the image of Mexico as a vacation destination and the influence of geographical location upon that image. Journal of Travel Research, 17(4), 18-23.

Hair, J. F., Black, W. C., Babin, B. J., \& Anderson, R. E. (2010). Multivariate data analysis (7th Ed.). Upper Saddle River, NJ: Pearson Prentice Hall.

Hair, J. F., Ringle, C. M., \& Sarstedt, M. (2011). PLS-SEM: Indeed a silver bullet. Journal of Marketing Theory and Practice, 19(2), 139-152.

Hanlan, J., \& Kelly, S. (2005). Image formation, information sources and an iconic Australian tourist destination. Journal of Vacation Marketing, 11(2), 163-177.

Henseler, J., Ringle, C., \& Sarstedt, M. (2015). A new criterion for assessing discriminant validity in variance-based structural equation modeling. Journal of the Academy of Marketing Science, 43(1), 115-135.

Horng, J. S., Liu, C. H., Chou, H. Y., \& Tsai, C. Y. (2012). Understanding the impact of culinary brand equity and destination familiarity on travel intentions. Tourism Management, 33(4), 815-824.

Kayak, M., Kozak, M., \& Moslehpour, M. (2013). How perceived global brands influence consumer purchasing behaviour of Starbucks. In M. Kozak and N. Kozak, Aspects of Tourist Behaviour. Newcastle, UK: Cambridge Scholars Publishing.

Keller, K. L. (1993). Conceptualizing, Measuring, and Managing Customer-Based Brand Equity. Journal of Marketing, 57(1), 1-22.

Kim, H. B., \& Kim, W. G. (2005). The relationship between brand equity and firms' performance in luxury hotels and chain restaurant. Tourism Management, 26(4), 549-560.

Kim, T., Kim, W. G., \& Kim, H. B. (2009). The effects of perceived justice on recovery satisfaction, trust, word-of-mouth, and revisit intention in upscale hotels. Tourism Management, 30(1), 51-62.

Kladou, S., \& Kehagias, J. (2014) Developing a structural brand equity model for cultural destinations. Journal of Place Management and Development, 7(2), 112 - 125.

Konecnik, M, \& Gartner, W. C. (2007). Customer-based brand equity for a destination. Annals of Tourism Research, 34(2), 400-421.

Lee, J. S., \& Back, K. J. (2008). Attendee-based brand equity. Tourism Management, 29(2), 331-344. 
Park, S. Y., \& Petrick, J. F. (2006). Destinations' perspectives of branding. Annals of Tourism Research, 33(1), 262-265.

Qu, H., Kim, L. H., \& Im, H. H. (2011). A model of destination branding: Integrating the concepts of the branding and destination image. Tourism Management, 32(3), 465-476.

Steenkamp, J. B. E. M., Batra, R., \& Alden, D. L. (2003). How perceived brand globalness creates brand value. Journal of International Business Studies, 34(1), 53-65.

Strizhakova, Y., Coulter, R. A., \& Price, L. L. (2011). Branding in a global marketplace: The mediating effects of quality and self-identity brand signals. International Journal of Research in Marketing, 28(4), 342-351.

Tasci, A. D. A., \& Kozak, M. (2006). Destination brands vs destination images: do we know what we mean? Journal of Vacation Marketing, 12(4), 299-317.

Tasci, A. D. A., Gartner, W., \& Cavusgil, S. T. (2007). Measurement of destination brand bias using a quasi-experimental design. Tourism Management, 28(6), 1529-1540.

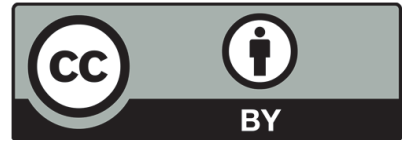

(C) 2016 by the authors; licensee Growing Science, Canada. This is an open access article distributed under the terms and conditions of the Creative Commons Attribution (CC-BY) license (http://creativecommons.org/licenses/by/4.0/). 